\title{
Direct Measurement of Mercury Deposition at Rural and Suburban Sites in Washington State, USA
}

\author{
Marc W. Beutel ${ }^{1, *}$, Lanka DeSilva ${ }^{2,+}$ and Louis Amegbletor ${ }^{3}$ (D) \\ 1 Department of Civil and Environmental Engineering and Environmental Systems Graduate Group, \\ University of California, Merced, CA 95343, USA \\ 2 Department of Civil and Environmental Engineering, Washington State University, Pullman, WA 99164, USA; \\ ldesilva@ramboll.com \\ 3 Environmental Systems Graduate Group, University of California, Merced, CA 95343, USA; \\ lamegbletor@ucmerced.edu \\ * Correspondence: mbeutel@ucmerced.edu \\ † Current affiliation: Ramboll, Lynnwood, WA 98036, USA.
}

check for updates

Citation: Beutel, M.W.; DeSilva, L.; Amegbletor, L. Direct Measurement of Mercury Deposition at Rural and Suburban Sites in Washington State, USA. Atmosphere 2021, 12, 35. https://doi.org/10.3390/atmos12010035

Received: 26 November 2020 Accepted: 22 December 2020 Published: 30 December 2020

Publisher's Note: MDPI stays neutral with regard to jurisdictional clai$\mathrm{ms}$ in published maps and institutional affiliations.

Copyright: (C) 2020 by the authors. Licensee MDPI, Basel, Switzerland. This article is an open access article distributed under the terms and conditions of the Creative Commons Attribution (CC BY) license (https:// creativecommons.org/licenses/by/ $4.0 /)$.

\begin{abstract}
Because of mercury's (Hg) capacity for long-range transport in the atmosphere, and its tendency to bioaccumulate in aquatic biota, there is a critical need to measure spatial and temporal patterns of $\mathrm{Hg}$ atmospheric deposition. Dry deposition of $\mathrm{Hg}$ is commonly calculated as the product of a measured atmospheric concentration and an assumed deposition velocity. An alternative is to directly assess $\mathrm{Hg}$ deposition via accumulation on surrogate surfaces. Using a direct measurement approach, this study quantified $\mathrm{Hg}$ deposition at a rural site (Pullman) and suburban site (Puyallup) in Washington State using simple, low-cost equipment. Dry deposition was measured using an aerodynamic "wet sampler" consisting of a Teflon plate, $35 \mathrm{~cm}$ in diameter, holding a thin layer $(2.5 \mathrm{~mm})$ of recirculating acidic aqueous receiving solution. In addition, wet $\mathrm{Hg}$ deposition was measured using a borosilicate glass funnel with a 20 -cm-diameter opening and a $1 \mathrm{~L}$ Teflon sampling bottle. $\mathrm{Hg}$ deposition was estimated based on changes in total $\mathrm{Hg}$ in the aqueous phase of the samplers. Dry $\mathrm{Hg}$ deposition was $2.4 \pm 1.4 \mathrm{ng} / \mathrm{m}^{2} \cdot \mathrm{h}$ (average plus/minus standard deviation; $n=4$ ) in Pullman and $1.3 \pm 0.3 \mathrm{ng} / \mathrm{m}^{2} \cdot \mathrm{h}(n=6)$ in Puyallup. Wet $\mathrm{Hg}$ deposition was $7.0 \pm 4.8 \mathrm{ng} / \mathrm{m}^{2} \cdot \mathrm{h}$ $(n=4)$ in Pullman and $1.1 \pm 0.2 \mathrm{ng} / \mathrm{m}^{2} \cdot \mathrm{h}(n=3)$ in Puyallup. Relatively high rates of $\mathrm{Hg}$ deposition in Pullman were attributed to regional agricultural activities that enhance mercury re-emission and deposition including agricultural harvesting and field burning. $\mathrm{Hg}$ concentration in precipitation negatively correlated with precipitation depth, indicating that $\mathrm{Hg}$ was scavenged from the atmosphere during the beginning of storm events. Because of their relative simplicity and robustness, direct measurement approaches such as those described in this study are useful in assessing $\mathrm{Hg}$ deposition, and for comparing results to less direct estimates and model estimates of $\mathrm{Hg}$ deposition.
\end{abstract}

Keywords: dry deposition; wet deposition; wet sampler; agricultural field burning; AIRPACT

\section{Introduction}

Mercury $(\mathrm{Hg})$ has a unique ability for long-range transport in the atmosphere [1]. Combined with the tendency of $\mathrm{Hg}$ to bioaccumulate in aquatic biota, atmospheric deposition of $\mathrm{Hg}$ is a worldwide health concern [2]. Natural sources of $\mathrm{Hg}$ are geogenic and include releases from outgassing mantel and crustal materials, volcanoes, and geothermal regions [3]. Key anthropogenic sources of atmospheric $\mathrm{Hg}$ include coal combustion, artisanal and small-scale gold mining, metal production, and cement production [4]. Direct anthropogenic sources account for $\sim 30 \%$ of total $\mathrm{Hg}$ emissions to the atmosphere, natural emissions account for $\sim 10 \%$, and re-emission of previously deposited $\mathrm{Hg}$ from oceans and soils make up the remaining $60 \%$ [4,5]. A substantial fraction of deposited $\mathrm{Hg}$ ends up in aquatic ecosystems where it can accumulate in aquatic biota as toxic methylmercury $[5,6]$. As a result of widespread $\mathrm{Hg}$ deposition in North America, 6.6 million lake 
hectares in the U.S. have fish consumption advisories in place due to elevated concentrations of $\mathrm{Hg}$ in fish tissue, and 28 states including Washington have statewide fish consumption advisories due mainly to $\mathrm{Hg}$ contamination [7]. An important source of $\mathrm{Hg}$ deposition in the Pacific Northwest region of the U.S., the geographical focus of this study, is the long-range transport of $\mathrm{Hg}$ emissions from Asia [8].

The atmospheric cycling of $\mathrm{Hg}$ is complex, but many key processes are known $[1-3,9,10]$. Atmospheric $\mathrm{Hg}$ is dominated by gaseous elemental $\mathrm{Hg}$ (GEM), which has a residence time of months, allowing for long-range transport in the atmosphere. GEM can be transformed to gaseous oxidized $\mathrm{Hg}(\mathrm{GOM})$ in the atmosphere in the presence of ozone, chlorine gas, hydroxyl radical and bromine compounds. Because of its greater solubility and reactivity, GOM has an atmospheric residence time of days to weeks. GOM, with its relatively low vapor pressure, can partition onto particulate matter to form particulate-bound $\mathrm{Hg}$ (PBM), which, like GOM, has a relatively short residence time that is dependent on particle size. The surface flux of $\mathrm{Hg}$ is bidirectional since deposited $\mathrm{Hg}$ can efflux back into the atmosphere as GEM. Hg deposition can occur as dry or wet deposition. Depending on season and setting, dry deposition can be dominated by the deposition of gaseous $\mathrm{Hg}$ species or by the deposition of PBM. The source of $\mathrm{Hg}$ in wet deposition includes incloud oxidation of GEM to soluble $\mathrm{Hg}$ (II) and scavenging of GOM and PBM out of the atmosphere.

Rates of dry deposition are commonly calculated as the product of a measured $\mathrm{Hg}$ atmospheric concentration and an assumed deposition velocity [11]. The magnitude of deposition velocity is relatively small for GEM $(0.1-0.4 \mathrm{~cm} / \mathrm{s})$, moderate for PBM $(0.02-2 \mathrm{~cm} / \mathrm{s})$, and large for GOM $(0.5-6 \mathrm{~cm} / \mathrm{s})$. An alternative method to estimate $\mathrm{Hg}$ dry deposition is a direct approach that captures deposited $\mathrm{Hg}$ onto a variety of abiotic surfaces including water surfaces, membranes and artificial turf [12-15]. This method has the advantage of obviating the need to assume a deposition velocity. However, uncertainty exists as to how well surrogate surfaces mimic environmental surfaces. In this study, we used a direct wet-sampler to measure dry deposition in the summer and fall of 2011 to compare patterns at a rural site in eastern Washington and a suburban site in western Washington. Wet deposition was also assessed with a simple funnel and Teflon sampling bottle. Since urban locations tend to have higher rates of $\mathrm{Hg}$ deposition, we anticipated that the urban site would exhibit higher rates of $\mathrm{Hg}$ deposition. However, as illustrated in this study and acknowledged in other studies, this linkage can be weak since $\mathrm{Hg}$ deposition is affected not only by local emissions but also atmospheric processes [1,16]. We also assessed the significance of ephemeral summer storms on the annual $\mathrm{Hg}$ deposition budget for the rural site in eastern Washington and compared directly measured $\mathrm{Hg}$ deposition to results from a regional air quality model (AIRPACT-3).

This project was motivated by calls for expanded efforts to complement indirect measurement of $\mathrm{Hg}$ deposition with direct measurements that assess both dry and wet $\mathrm{Hg}$ deposition using inexpensive and simple approaches [14,17-19]. It was also motivated by the limited amount of $\mathrm{Hg}$ deposition data in Washington State and the greater Pacific Northwest [20-22]. While the data presented here is from a study several years ago, we were prompted to publish it because of its good fit with this special issue of Atmosphere focusing on atmospheric mercury monitoring. We believe our study's results are still relevant and highlight the utility of direct monitoring of mercury deposition.

\section{Experiments}

\subsection{Sampling Sites}

Hg deposition was measured at two contrasting sites in Washington State (Figure 1). One site was located in Pullman in rural eastern Washington $\left(46.733^{\circ} \mathrm{N}, 117.172^{\circ} \mathrm{W}\right)$. Samples were collected on the rooftop of Dana Hall, a three-story building ( $9.8 \mathrm{~m}$ height) on the Washington State University (WSU) campus. Pullman is surrounded by wheat, barley, lentil, and pea agricultural fields. The regional climate is semi-arid with hot, dry summers and cold, wet winters. Annual precipitation is $\sim 50 \mathrm{~cm} / \mathrm{y}$. Of potential 
importance to this study, agricultural field burning in the region is common in the fall, mainly during August and September. Dry deposition samples were collected in Pullman during four precipitation-free sampling events in August-September 2011. Wet deposition was measured during four events in June, July and October 2011. Rainfall events ranged in duration from 2 to $21 \mathrm{~h}$ and had mean precipitation intensity of $0.08-0.61 \mathrm{~mm} / \mathrm{h}$.

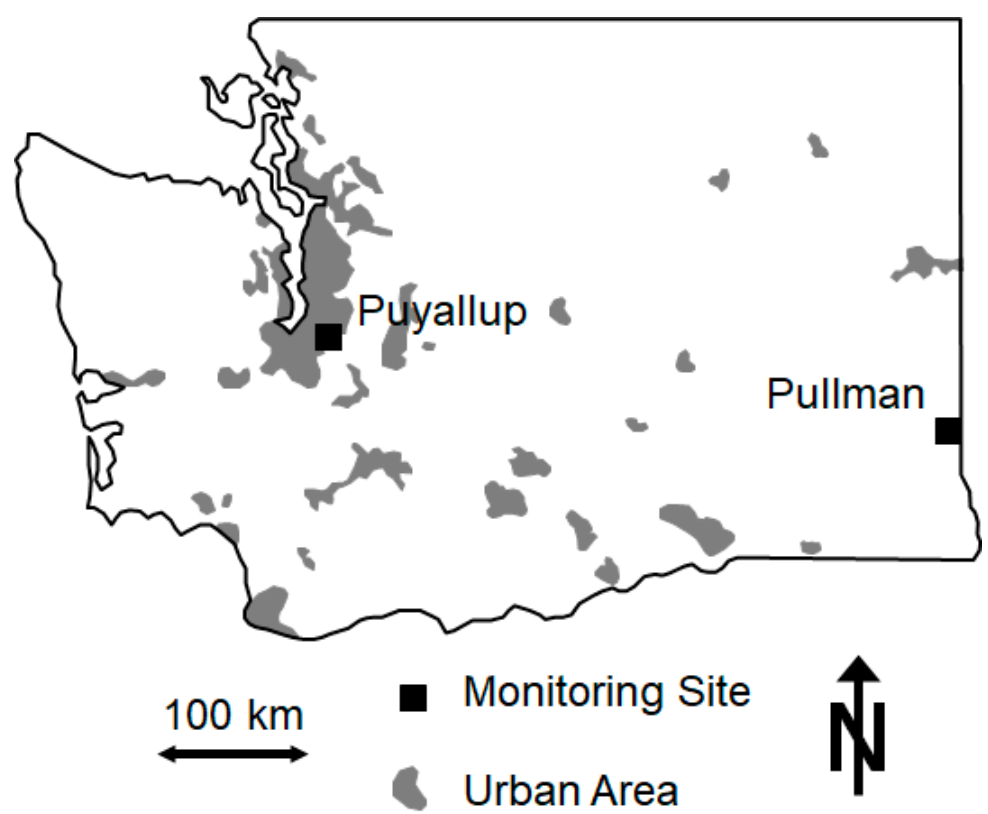

Figure 1. Site locations of deposition monitoring.

The other site was located in suburban Puyallup in western Washington $\left(47.185^{\circ} \mathrm{N}\right.$, $122.292^{\circ}$ W). Samples were collected on the rooftop of the Avian Health and Food Safety Laboratory ( $4 \mathrm{~m}$ height) at the WSU Puyallup Research and Extension Center. The site is southeast of the heavily urbanized and industrialized Seattle-Tacoma metropolitan area. The Centralia Power Plant, which is $73 \mathrm{~km}$ southwest of the study site, is the only coal fire power plant in Washington and is a major source of $\mathrm{Hg}$ deposition to western Washington. Puyallup is also relatively vulnerable to $\mathrm{Hg}$ deposition from long-range atmospheric transport of $\mathrm{Hg}$ from Asia [9]. The regional climate of Puyallup is cool with dry summers and mild, wet, and cloudy winters. Annual precipitation is $\sim 100 \mathrm{~cm} / \mathrm{y}$. Dry deposition samples were collected during six sampling events in September-October 2011. Wet deposition was measured during three events in September-October 2011. Rainfall events ranged in duration from 16 to $56 \mathrm{~h}$ and had mean precipitation intensity of $0.30-0.38 \mathrm{~mm} / \mathrm{h}$.

\subsection{Dry Deposition Sampling}

The dry deposition sampling apparatus was based on [23,24]. A wet sampler was used that collected dry deposition in an acidic aqueous solution that was analyzed for total $\mathrm{Hg}(\mathrm{THg})$. The wet sampler was anticipated to mainly collect deposited GOM and PBM, but also some GEM since the solubility of elemental $\mathrm{Hg}$ is enhanced in low-pH water [25]. The sampler consisted of a Teflon plate, $35 \mathrm{~cm}$ in diameter, holding a thin layer $(2.5 \mathrm{~mm}$ ) of aqueous receiving solution (Figure 2). The plate was held by a collector with an outer edge shaped like an airfoil to minimize air flow disturbance over the water surface. The receiving solution was continuously circulated onto the plate via a pump and Teflon tubing. Solution was discharge onto the top of the plate then flowed over four weirs on the outer edge of the plate and into the collector, which was connected to a $5 \mathrm{~L}$ glass reservoir. The reservoir was chilled by a refrigeration unit to $10^{\circ} \mathrm{C}$ to minimize evaporative losses. 


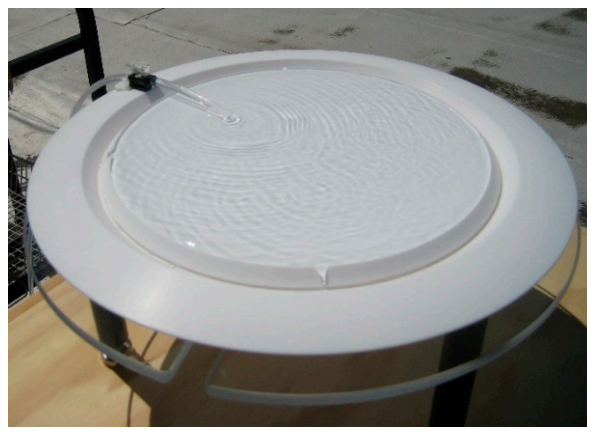

(a)

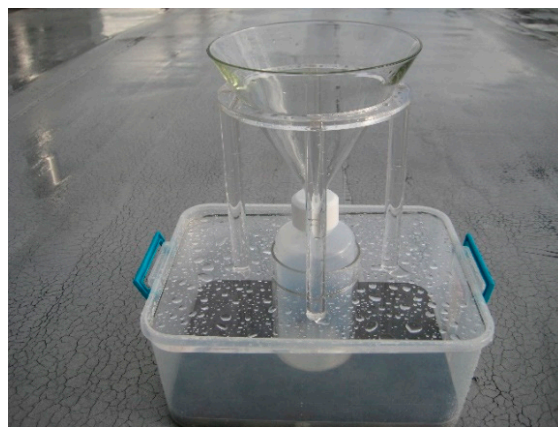

(b)

Figure 2. (a): Dry deposition sampler. Plate diameter is $35 \mathrm{~cm}$. (b): Wet deposition sampler. Funnel diameter is $20 \mathrm{~cm}$.

Before each sampling event, the water surface holder, plate, tubing, and reservoir were cleaned thoroughly with $25 \%$ nitric acid and triple rinsed with reagent grade deionized water. The reservoir was filled with $5 \mathrm{~L}$ of $0.05 \mathrm{M}$ hydrochloric acid $(\mathrm{HCl})$ receiving solution which was circulated through the system at a rate of $200 \mathrm{~mL} / \mathrm{min}$. After $30 \mathrm{~min}$ of operation, an initial sample of receiving solution was collected for later $\mathrm{Hg}$ analysis. The system was operated for several days and a second sample of receiving solution was collected at the end of the sampling event. To determine the final volume, the remaining receiving solution was decanted and weighed. In the first Pullman and all Puyallup sampling events, two samples were collected, one mid-way through the sampling event and another at the end of the sampling event.

Samples were preserved with $1 \%$ bromine monochloride and analyzed in triplicate for THg based on United States Environmental Protection Agency (USEPA) Method 1631 [26] on a Brooks Rand MERX-T mercury auto analyzer. The method detection limit for THg is $0.2 \mathrm{ng} / \mathrm{L}$. Standard quality control procedures for $\mathrm{THg}$ analyses included calibration blanks (acceptable range $<50 \mathrm{pg}$; mean $=2.98 \mathrm{pg}, n=20$ ), matrix spike samples (acceptable range $71-125 \%$; mean recovery $=88.6 \%, n=15$ ), and ongoing precision (acceptable range $77-123 \%$; mean recovery $=96.6 \%, n=24$ ). Mass accumulation of $\mathrm{THg}$ was estimated as the difference between the concentration multiplied by associated volume of receiving solution at the end and beginning of the sampling event. Dry $\mathrm{Hg}$ deposition in $\mathrm{ng} / \mathrm{m}^{2} \cdot \mathrm{hr}$ was calculated as the mass accumulation divided by the area of the plate $\left(0.0962 \mathrm{~m}^{2}\right)$ and the duration of the sampling event.

\subsection{Wet Deposition Sampling}

Wet deposition sampling apparatus was based on [27]. The sampler included four components: a borosilicate glass funnel with a 20-cm-diameter opening, a Teflon adaptor, a 1 L Teflon sampling bottle, and a Plexiglas holder (Figure 2). Prior to each sampling event, the borosilicate glass funnel, adaptor, and sampling bottle were cleaned thoroughly with $25 \%$ nitric acid and triple rinsed with reagent grade deionized water. Twenty $\mathrm{ml}$ of $0.08 \mathrm{M}$ $\mathrm{HCl}$ receiving solution was added to the sample bottle to enhance capture and preservation of $\mathrm{Hg}$ in collected precipitation. A subsample of receiving solution was collected at the beginning of the sampling event for later THg analysis. At the end of the sampling event, collected rainwater was weighed to determine the volume of precipitation, then a sample was collected. Samples were preserved and analyzed for THg as described above for the dry deposition monitoring, with the exception that Pullman June and July samples were not run in triplicate due to limited sample volume. Mass accumulation of $\mathrm{Hg}$ was estimated as the $\mathrm{THg}$ concentration in the rainfall-receiving solution mixture collected at the end of the sampling event multiplied by its volume, corrected for the initial THg mass in the receiving solution. Wet $\mathrm{Hg}$ deposition in $\mathrm{ng} / \mathrm{m}^{2} \cdot \mathrm{hr}$ was calculated as mass accumulation divided by the area of the funnel $\left(0.0314 \mathrm{~m}^{2}\right)$ and the duration of the sampling event. 


\section{Results}

\subsection{Dry Deposition}

Dry Hg deposition measured in Pullman ranged from 1.0 to $4.3 \mathrm{ng} / \mathrm{m}^{2} \cdot \mathrm{h}$ and averaged $2.4 \mathrm{ng} / \mathrm{m}^{2} \cdot \mathrm{h}$ (Table 1, Figure 3). The high deposition rate observed in late August $\left(4.3 \mathrm{ng} / \mathrm{m}^{2} \cdot \mathrm{h}\right)$ corresponded with smoky conditions in Pullman. High air temperatures $\left(12-26^{\circ} \mathrm{C}\right)$, low relative humidity $(31-54 \%)$, and elevated wind speeds $(0.8-3.1 \mathrm{~m} / \mathrm{s})$ during August sampling resulted in high rates of evaporation [28]. Normalized to the area of the sampler, evaporation rates (5.4-5.9 mm/d) were similar to the historical mean August pan evaporation rate for the area $(6.7 \mathrm{~mm} / \mathrm{d})$ [29]. Dry $\mathrm{Hg}$ deposition in Puyallup ranged from 0.8 to $1.6 \mathrm{ng} / \mathrm{m}^{2} \cdot \mathrm{h}$ and averaged $1.3 \mathrm{ng} / \mathrm{m}^{2} \cdot \mathrm{h}$. Relative to Pullman, dry deposition in Puyallup was lower in magnitude and less variable. Measured evaporation rates were relatively low and corresponded with low air temperature $\left(11-22^{\circ} \mathrm{C}\right)$, high relative humidity $(66-88 \%)$, and low wind speed $(0-0.6 \mathrm{~m} / \mathrm{s})$ during September sampling [28]. Estimated evaporation rates for the three events $(0.3-2.0 \mathrm{~mm} / \mathrm{d})$ were lower than the historical mean September pan evaporation rate for the region $(2.4 \mathrm{~mm} / \mathrm{d})$ [29].

Table 1. Mercury dry deposition.

\begin{tabular}{|c|c|c|c|c|c|c|c|}
\hline Date & $\begin{array}{l}\text { Duration } \\
\text { (Days) }\end{array}$ & $\begin{array}{l}\text { Initial Vol } \\
\text { (L) }\end{array}$ & $\begin{array}{l}\text { Final Vol } \\
\text { (L) }\end{array}$ & $\begin{array}{l}\text { Evap Rate } \\
\text { (L/d) }\end{array}$ & $\begin{array}{c}\text { Initial Total } \mathrm{Hg}^{\mathrm{a}} \\
\text { (ng/L) }\end{array}$ & $\begin{array}{c}\text { Final Total } \mathrm{Hg}^{\text {a }} \\
(\mathrm{ng} / \mathrm{L})\end{array}$ & $\begin{array}{c}\text { Hg Dry Dep } \\
\left(\mathrm{ng} / \mathrm{m}^{2} \cdot \mathrm{h}\right)\end{array}$ \\
\hline \multicolumn{8}{|c|}{ Pullman, WA } \\
\hline 15-18 Aug & 2.77 & 4.87 & $3.28^{c}$ & \multirow{2}{*}{$0.57^{\mathrm{d}}$} & 1.57 & 7.12 & 2.5 \\
\hline 18-22 Aug & 3.96 & 3.02 & 0.75 & & 7.12 & 41.1 & 1.0 \\
\hline \multirow{2}{*}{$\begin{array}{l}23-28 \text { Aug } \\
29 \text { Aug-5 } \\
\text { Sep }\end{array}$} & 5.04 & 4.74 & 1.96 & 0.55 & 1.43 & 28.9 & 4.3 \\
\hline & 7.11 & 4.74 & 1.02 & 0.52 & 1.26 & 30.8 & 1.6 \\
\hline \multicolumn{8}{|c|}{ Puyallup, WA } \\
\hline 12-15 Sep & 3.03 & 4.75 & $4.26^{c}$ & \multirow[b]{2}{*}{$0.16^{\mathrm{d}}$} & 1.37 & 4.01 & 1.5 \\
\hline 15-17 Sep & 1.64 & 4.01 & 3.74 & & 4.01 & 5.14 & 0.8 \\
\hline 21-23 Sep & 2.05 & 4.75 & $4.69^{c}$ & \multirow{2}{*}{$0.03^{\mathrm{d}}$} & 0.79 & 2.37 & 1.6 \\
\hline 23-25 Sep & 1.74 & 4.43 & 4.38 & & 2.37 & 3.45 & 1.2 \\
\hline \multirow{2}{*}{$\begin{array}{l}27-29 \text { Sep } \\
29 \text { Sep-2 }\end{array}$} & 2.00 & 4.75 & $4.37^{\mathrm{c}}$ & \multirow{2}{*}{$0.19^{d}$} & 0.68 & 2.21 & 1.4 \\
\hline & 2.97 & 4.11 & 3.55 & & 2.21 & 4.48 & 1.0 \\
\hline
\end{tabular}

${ }^{a}$ Average of triplicate analysis. ${ }^{b}$ Deposition based on sampler cross-sectional area of $0.096 \mathrm{~m}^{2} .{ }^{c}$ Volume estimated based on evaporation rate over entire event. ${ }^{\mathrm{d}}$ Evaporation rate based on total volume loss over entire event.

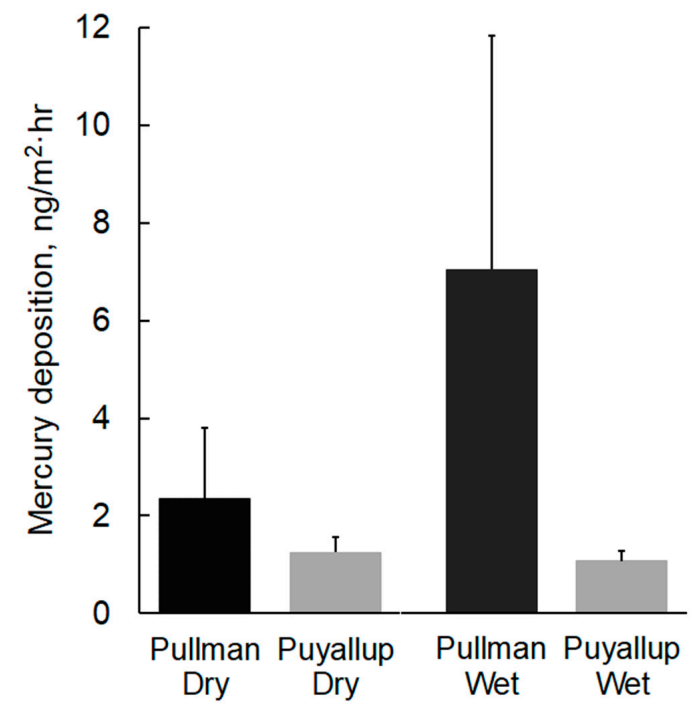

Figure 3. Dry and wet $\mathrm{Hg}$ deposition at Pullman and Puyallup, WA. Values are mean plus one standard deviation $(n=3-6)$. 


\subsection{Wet Deposition}

Wet $\mathrm{Hg}$ deposition measured in Pullman ranged from 1.8 to $12.8 \mathrm{ng} / \mathrm{m}^{2} \cdot \mathrm{h}$ and averaged $7.0 \mathrm{ng} / \mathrm{m}^{2} \cdot \mathrm{d}$ (Table 2, Figure 3). Deposition rates for the three storm events in June/July were an order of magnitude higher than for the October event. Two summer events in June and July with low precipitation intensity $(<0.17 \mathrm{~mm} / \mathrm{h})$ had relatively high mean $\mathrm{Hg}$ concentrations in precipitation $(>56 \mathrm{ng} / \mathrm{L}$ ). Wet $\mathrm{Hg}$ deposition in Puyallup in September/October ranged from 0.9 to $1.3 \mathrm{ng} / \mathrm{m}^{2} \cdot \mathrm{h}$. Mean $\mathrm{Hg}$ concentrations in Puyallup precipitation ranged from 2.3 to $3.5 \mathrm{ng} / \mathrm{L}$. As with dry deposition, wet deposition rates and $\mathrm{Hg}$ concentrations in precipitation were lower and less variable in Puyallup when compared to Pullman.

Table 2. Mercury wet deposition.

\begin{tabular}{|c|c|c|c|c|c|c|c|c|}
\hline Date & $\begin{array}{l}\text { Duration } \\
\text { (h) }\end{array}$ & $\begin{array}{l}\text { Initial Vol } \\
\quad(\mathrm{mL})\end{array}$ & $\begin{array}{l}\text { Final Vol } \\
\quad(\mathrm{mL})\end{array}$ & $\begin{array}{l}\text { Precip } \\
(\mathrm{mm} / \mathrm{h})\end{array}$ & $\begin{array}{c}\text { Initial Total } \\
\mathrm{Hg}^{\mathrm{a}} \\
(\mathrm{ng} / \mathrm{L})\end{array}$ & $\begin{array}{c}\text { Final Total } \mathrm{Hg}^{\mathrm{a}} \\
(\mathrm{ng} / \mathrm{L})\end{array}$ & $\begin{array}{c}\text { Hg Wet Dep } \\
\left(\mathrm{ng} / \mathrm{m}^{2} \cdot \mathrm{h}\right)\end{array}$ & $\begin{array}{l}\text { Precip Hg } \\
\text { (ng/L) }\end{array}$ \\
\hline \multicolumn{9}{|c|}{ Pullman, WA } \\
\hline $\begin{array}{c}28-29 \\
\text { June }\end{array}$ & 3.50 & 20 & 38.9 & 0.17 & 0.81 & $36.1^{b}$ & 12.8 & 73.4 \\
\hline $\begin{array}{c}\text { 12-13 } \\
\text { July }\end{array}$ & 11.0 & 20 & 48.5 & 0.08 & 0.90 & $33.8^{\mathrm{b}}$ & 4.8 & 56.9 \\
\hline 14 July & 2.17 & 20 & 61.2 & 0.61 & 0.88 & $9.84^{b}$ & 8.7 & 14.2 \\
\hline 10-11 Oct & 21.0 & 20 & 210 & 0.29 & 0.27 & 5.74 & 1.8 & 6.32 \\
\hline \multicolumn{9}{|c|}{ Puyallup, WA } \\
\hline 17-19 Sep & 37.9 & 20 & 467 & 0.38 & 0.71 & 2.27 & 0.89 & 2.34 \\
\hline 25-27 Sep & 55.4 & 20 & 533 & 0.30 & 0.86 & 3.28 & 1.0 & 3.37 \\
\hline $2-3 \mathrm{Oct}$ & 16.1 & 20 & 209 & 0.38 & 0.62 & 3.18 & 1.3 & 3.45 \\
\hline
\end{tabular}

a Average of triplicate analysis. ${ }^{b}$ Single analysis due to low precipitation volume. ${ }^{c}$ Deposition based on funnel cross sectional area of $0.031 \mathrm{~m}^{2}$.

\section{Discussion}

\subsection{Dry Deposition}

Dry $\mathrm{Hg}$ deposition rates observed in this study, typically $1-2 \mathrm{ng} / \mathrm{m}^{2} \cdot \mathrm{h}$, were similar to a limited number of studies that report direct measurements of dry $\mathrm{Hg}$ deposition using wet samplers with acidified de-ionized water as receiving solution. Dry $\mathrm{Hg}$ deposition measured in Komae, a heavily industrialized city in the western Tokyo metropolitan area, ranged from 0.5 to $3 \mathrm{ng} / \mathrm{m}^{2} \cdot \mathrm{h}(n=5)$ [24]. Related long-term studies measured $\mathrm{Hg}$ deposition monthly at 10 sites in Japan over multiple years. Mean dry deposition ranged from $0.4-2 \mathrm{ng} / \mathrm{m}^{2} \cdot \mathrm{h}$ and higher deposition rates were associated with urban and industrial areas [30,31]. Dry deposition ranging from 0.4 to $1.7 \mathrm{ng} / \mathrm{m}^{2} \cdot \mathrm{h}(n=5)$ was measured in rural New York State [32]. Some studies have used un-acidified de-ionized water as receiving water in passive static samplers and report dry deposition rates ranging from 0.5 to $2 \mathrm{ng} / \mathrm{m}^{2} \cdot \mathrm{h}$ in an urban site in Ohio [14] and $0.3-0.5 \mathrm{ng} / \mathrm{m}^{2} \cdot \mathrm{h}$ in the Florida Everglades [33]. Measured deposition rates generally increase with the addition of acid, presumably due to enhanced capture and retention of GEM [25].

In an effort to compare our direct measurements of dry deposition with those estimated based on atmospheric Hg monitoring, we searched the USEPA AirData Air Quality Monitors website and found relevant data in the National Air Toxics Trends Stations (NATTS) database [34]. While no stations were located in the rural eastern portion of Washington, a station was located near our Puyallup site (site code 53/033/0080; 47.56824 ${ }^{\circ} \mathrm{N}$, $122.309^{\circ} \mathrm{W}$ ). Reported arithmetic mean daily values for $\mathrm{Hg}$ PM10 concentrations for 2011 ranged from 0 to $0.04 \mathrm{ng} / \mathrm{m}^{3}$ over the year $(n=60)$ and were $\sim 0.01 \mathrm{ng} / \mathrm{m}^{3}$ during this study (Table S1). Back calculating a depositional velocity during the study period as the mean measured dry deposition flux $\left(1.25 \mathrm{ng} / \mathrm{m}^{2} \cdot \mathrm{h}\right.$; Table 1$)$ divided by the mean measured Hg PM10 (0.0075 ng $/ \mathrm{m}^{3}$; Table S1) yields a deposition velocity on the order of $2.6 \mathrm{~cm} / \mathrm{s}$, 
which is similar in magnitude but on the high end of deposition velocity typically reported for PBM $(0.02-2 \mathrm{~cm} / \mathrm{s})$ [11].

The rural site in Pullman exhibited rates of dry $\mathrm{Hg}$ deposition that were somewhat higher in magnitude when compared to the suburban Puyallup site. While rural, the landscape around Pullman is intensely managed for agricultural production. When crops are harvested, $\mathrm{Hg}$ deposited on soil and plants during the growing season can be dispersed into the atmosphere on dust and deposited back onto the landscape, resulting in enhanced localized Hg deposition [35]. Agricultural field tilling has also been implicated in elevated levels of atmospheric $\mathrm{Hg}$ and downwind $\mathrm{Hg}$ deposition [36]. Wildfires and agricultural fires can also substantially enhance $\mathrm{Hg}$ emissions via combustion of biomass, litter and organic soils, with the magnitude of emissions apparently corresponding with fire severity [10]. A 3-4 fold increase in total gaseous $\mathrm{Hg}$ was measured above wild and agricultural fires in eastern Washington and Oregon [37]. Hg emitted via fires can enhance regional $\mathrm{Hg}$ deposition rates [3]. A 12-fold increase in PBM deposition was measured in New Mexico resulting from transport of smoke from a large forest fire in Arizona [38].

A review of regional burn permits, along with regional meteorology and air quality, suggests that the relatively elevated dry $\mathrm{Hg}$ deposition in Pullman measured between 15 August and 5 September was affected by agricultural field burning. Burn permits allotted by the Washington State Department of Ecology indicated that agricultural field burns totaling 400 ha occurred in Walla Walla County, $160 \mathrm{~km}$ southwest of Pullman, between 15 and 27 August. Prevailing wind direction in the region during August 2011 was generally southwesterly. Mean hourly wind direction from 15 to 27 August was $236^{\circ} \pm 68^{\circ}$ (mean \pm standard deviation, $n=142$ ) in Pullman (http://mesowest.utah.edu/; station KPUW) and $183^{\circ} \pm 70^{\circ}(n=266)$ in Walla Walla (http://mesowest.utah.edu/; station KALW). Back trajectory modeling using HYSPLIT, a hybrid single-particle lagrangian integrated trajectory model hosted by the Nation Oceanic and Atmospheric Administration (http:/ / www.arl.noaa.gov/HYSPLIT.php), confirmed that air parcels in Pullman generally passed through the Walla Walla region throughout mid to late August 2011 (Figure S1). In addition, because wildfires and prescribed fires are known to be substantial sources of atmospheric particulate matter [39], we assessed PM2.5 concentrations reported via the USEPA Outdoor Air Quality Data repository (https://www.epa.gov/ outdoor-air-quality-data / download-daily-data) for Pullman (station 530710005) and Walla Walla (station 530750003). PM2.5 concentrations were generally $<5 \mu \mathrm{g} / \mathrm{m}^{3}$ in July and $<5 \mu \mathrm{g} / \mathrm{m}^{3}$ in August, with levels increasing to $>10 \mu \mathrm{g} / \mathrm{m}^{3}$ at times in late August and early September (Figure S2), suggesting that smoky conditions were present in Pullman when dry deposition measurements were performed in this study. Relatively high levels of PM2.5 in Pullman between 23 and 28 August (Figure S2) corresponded with the highest measured $\mathrm{Hg}$ dry deposition of $4.3 \mathrm{ng} / \mathrm{m}^{2} \cdot \mathrm{h}$ (Table 1 ), further suggesting a linkage between smoky conditions and $\mathrm{Hg}$ deposition.

\subsection{Wet Deposition}

Except for the June and July events in Pullman, which had elevated THg concentrations in precipitation of $73 \mathrm{ng} / \mathrm{L}$ and $57 \mathrm{ng} / \mathrm{L}$, respectively, the results of this study were comparable to concentrations reported worldwide, which typically range from 1 to $15 \mathrm{ng} / \mathrm{L}$ [40]. Concentrations are also similar to those measured in California precipitation, which ranged from 1 to $28 \mathrm{ng} / \mathrm{L}$ and averaged $4 \mathrm{ng} / \mathrm{L}(n=46)$ [41]. The extreme concentrations measured in Pullman appear to be relatively uncommon at other reported monitoring sites. In hundreds of precipitation samples from Europe and China, 95th percentile $\mathrm{THg}$ concentrations rarely exceeded $40 \mathrm{ng} / \mathrm{L}$ [40]. The high Pullman THg concentrations were undoubtedly related to the small precipitation amount associate with these monitored events. While annual $\mathrm{Hg}$ deposition generally correlates with total annual precipitation, $\mathrm{THg}$ concentration in collected precipitation generally shows a negative correlation with precipitation amount [1]. This observation is attributed to scavenging of $\mathrm{Hg}$ from the air column early during storm events and subsequent dilution of the accumulating sample 
later in the event. The relationship between THg concentration and precipitation amount was apparent in our pooled samples (Figure 4). This phenomenon, combined with the fact that agricultural activities can enhance $\mathrm{Hg}$ re-emission from the landscape [35,36], explains the high $\mathrm{Hg}$ concentrations in precipitation observed during small rain events in Pullman in June and July.

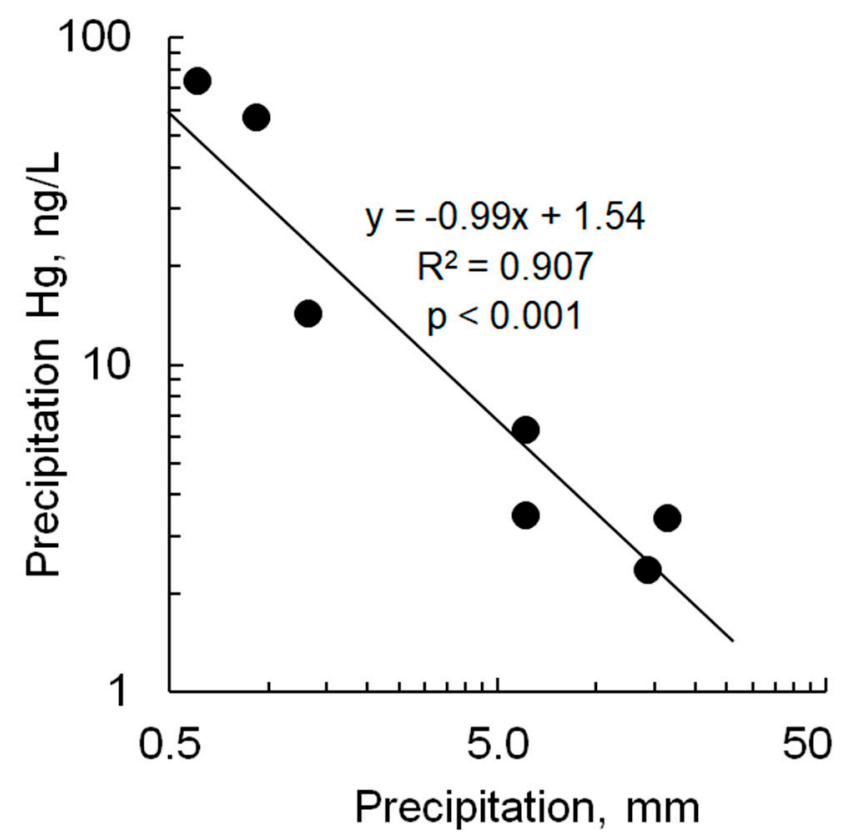

Figure 4. Relationship between $\mathrm{Hg}$ concentration in precipitation and precipitation depth for data for Pullman and Puyallup, WA. Line is linear regression.

While brief in duration, wet $\mathrm{Hg}$ deposition via ephemeral storm events observed in Pullman in June and July deposited a similar magnitude of $\mathrm{Hg}$ to longer storm events. For example, the 3.5-h-long June storm event deposited $45 \mathrm{ng} / \mathrm{m}^{2}$ while the 21 -h-long October storm event deposited $39 \mathrm{ng} / \mathrm{m}^{2}$. While the frequency of monitoring in this study was admittedly limited, the data obtained can be used to assess patterns of $\mathrm{Hg}$ deposition during the dry period in Pullman (May-September 2011). Based on an examination of 2011 precipitation patterns for the dry period in Pullman and mass balance considerations, ephemeral storm events may have accounted for $\sim 20 \%$ of dry-season $\mathrm{Hg}$ deposition (see Section S1 in Supplemental Material for additional details).

\subsection{Model Versus Direct Measurements of $\mathrm{Hg}$ Deposition}

AIRPACT-3 (Air Indicator Report for Public Access and Community Tracking) is a numerical air quality forecast system that operates daily for the Pacific Northwest. It estimates a range of air quality parameters including $\mathrm{Hg}$ dry and wet deposition (see Section S2 in Supplemental Material for additional details). The modeled rates of $\mathrm{Hg}$ deposition from AIRPACT-3 were generally lower, but of similar magnitude, compared to direct measurements in the field. For Pullman (Figure S3), modeled dry deposition typically ranged from 1 to $5 \mathrm{ng} / \mathrm{m}^{2} \cdot \mathrm{d}$ with occasional peaks of $20-40 \mathrm{ng} / \mathrm{m}^{2} \cdot \mathrm{d}$. Modeled peaks of dry $\mathrm{Hg}$ deposition were similar in magnitude but shorter in duration than direct measurements in mid-August $\left(37 \mathrm{ng} / \mathrm{m}^{2} \cdot \mathrm{d}\right)$ and early September $\left(39 \mathrm{ng} / \mathrm{m}^{2} \cdot \mathrm{d}\right)$. Modeled values were far below the extreme dry deposition rate of $103 \mathrm{ng} / \mathrm{m}^{2} \cdot \mathrm{d}$ measured in late August, likely associated with enhanced deposition from regional agricultural field burning. Modeled rates of wet deposition showed four events with substantial deposition $\left(>5 \mathrm{ng} / \mathrm{m}^{2} \cdot \mathrm{d}\right)$, one in June, one in July, and two in October. The July and October modeled deposition events coincided temporally with direct measurement field events, indicating that the model captured actual 
precipitation events, including occasional ephemeral storm events during the summer. However, direct measurements on those two dates were 5-10 times the model estimates.

For Puyallup, modeled dry deposition typically ranged from 3 to $15 \mathrm{ng} / \mathrm{m}^{2} \cdot \mathrm{d}$ with occasional peaks of $30-60 \mathrm{ng} / \mathrm{m}^{2} \cdot \mathrm{d}$ (Figure S4). Measured dry deposition was higher, ranging from 28 to $33 \mathrm{ng} / \mathrm{m}^{2} \cdot \mathrm{d}$. The model captured the temporal dynamics of precipitation events associated with direct field measurements fairly well, including dry conditions during all three dry deposition monitoring events and wet conditions during the second and third wet deposition monitoring events, though the timing of the third event in early October was a bit early relative to observed precipitation in Puyallup. Based on the last two monitoring events in late September and early October, direct measurements of wet deposition were 2-4 times higher than those predicted by the model. Considering that this study compared a limited number of direct measurements at discrete points in space to modeling results on a 12-km grid, rates of $\mathrm{Hg}$ deposition predicted by AIRPACT- 3 were reasonably close to direct measurements.

\section{Conclusions}

This study used a direct approach to assess the magnitude of dry and wet $\mathrm{Hg}$ deposition at a rural and suburban site in Washington. Measured values, generally ranging from 1 to $2 \mathrm{ng} / \mathrm{m}^{2} \cdot \mathrm{h}$, are some of the first published direct measurements of $\mathrm{Hg}$ deposition in the State. Key conclusions of the study include:

(1) Because of their relative simplicity and robustness, direct measurement approaches such as those described in this study are useful in assessing temporal and spatial patterns of $\mathrm{Hg}$ deposition, and for comparing results to less direct estimates of $\mathrm{Hg}$ deposition and estimates from numerical air quality models.

(2) Hg deposition can be substantial in rural regions with significant agricultural activities. Hg deposition rates at the rural study site (Pullman, Washington) were similar to or higher than deposition rates observed at the suburban study site (Puyallup, Washington), which was likely influenced by regional urban and industrial sources of $\mathrm{Hg}$.

(3) In rural agricultural areas, agricultural burning and associated re-emission and transport of previously deposited $\mathrm{Hg}$ can lead to elevated levels of $\mathrm{Hg}$ dry deposition. Rates of dry deposition in Pullman during smoky conditions indicative of agricultural burning were $\sim 2.5$ times the deposition rates observed during non-smoky conditions.

(4) $\mathrm{Hg}$ concentrations in precipitation correlated negatively with precipitation depth, suggesting that scavenging of PBM and GOM from the atmosphere at the beginning of storm events was an important wet deposition process.

(5) Ephemeral, short-term storm events at the rural Pullman site had elevated $\mathrm{Hg}$ concentrations. Mass balance estimates indicated that these Hg-rich storm events may account for a meaningful fraction $(\sim 20 \%)$ of dry season $\mathrm{Hg}$ deposition.

Supplementary Materials: The following are available online at https://www.mdpi.com/2073-4 433/12/1/35/s1: Table S1: Atmospheric Hg PM10 concentrations measured near Puyallup, WA; Figure S1: Example HYSPLIT back trajectories from Pullman, WA; Figure S2: PM2.5 data for Pullman and Walla Walla, WA; Section S1. Ephemeral Storm Events as Source of Hg Deposition; Section S2. AIRPACT-3 Air Quality Model; Figure S3: Measured and modeled dry and wet Hg deposition for Pullman, WA; Figure S4: Measured and modeled dry and wet $\mathrm{Hg}$ deposition for Puyallup, WA.

Author Contributions: Conceptualization, methodology, formal analysis, M.W.B. and L.D.; investigation, M.W.B., L.D. and L.A.; writing—original draft preparation, M.W.B. and L.D.; writing—review and editing, M.W.B. All authors have read and agreed to the published version of the manuscript.

Funding: This project was funded in part by the National Science Foundation (\#0846446) and the Atmospheric Policy Trajectory Program of the Washington State University Laboratory for Atmospheric Research.

Institutional Review Board Statement: Not applicable. 


\section{Informed Consent Statement: Not applicable.}

Data Availability Statement: Data collected in this study is, for the most part, presented in the paper and Supplemental Material. Any additional data is available upon request from the corresponding author.

Acknowledgments: This project was completed when Beutel was a faculty member and Lanka DaSilva was in the Environmental Engineering Master's degree program in the Civil and Environmental Engineering Department at Washington State University. We would like to thank the following people for their assistance during this project: Brian Lamb and Joseph Vaughn from Laboratory for Atmospheric Research at Washington State University, particularly for suppling HYSPLIT and AIRPACT-3 modeling results; John Stark and the staff of the Washington State University Puyallup Research and Extension Center; and Philip Kenyon, Washington State University undergraduate research assistant. We would also like to thank the anonymous reviewers for their constructive comments on the manuscript. The views expressed herein are solely those of the authors and do not represent the official policies or positions of any supporting agencies.

Conflicts of Interest: The authors declare no conflict of interest.

\section{References}

1. Lyman, S.N.; Cheng, I.; Gratz, L.E.; Weiss-Penzias, P.; Zhang, L. An updated review of atmospheric mercury. Sci. Total Environ. 2020, 707, 135575. [CrossRef] [PubMed]

2. Driscoll, C.T.; Mason, R.P.; Chan, H.M.; Jacob, D.J.; Pirrone, N. Mercury as a Global Pollutant: Sources, Pathways, and Effects. Environ. Sci. Technol. 2013, 47, 4967-4983. [CrossRef] [PubMed]

3. Schroeder, W.H.; Munthe, J. Atmospheric mercury-an overview. Atmos. Environ. 1998, 32, 809-822.

4. United Nations Environment Programme (UNEP). Global Mercury Assessment 2019: Sources, Emissions, Releases and Environmental Transport; UNEP Chemicals Branch: Geneva, Switzerland, 2019.

5. $\quad$ Lindberg, S.E.; Bullock, R.O.; Ebinghaus, R.; Engstrom, D.R.; Feng, X.; Fitzgerald, W.F.; Pirrone, N.; Prestbo, E.M.; Seignuer, C. A synthesis of progress and uncertainties in attributing the sources of mercury in deposition: Panel on source attribution of atmospheric mercury. Ambio 2007, 36, 19-32.

6. Swain, E.; Jakus, P.; Rice, G.; Lupi, F.; Maxson, P.; Pacyna, J.; Penn, A.; Spiegel, S.; Veiga, M. Socioeconomic consequences of mercury use and pollution. Ambio 2007, 36, 45-61.

7. United State Environmental Protection Agency (USEPA). Biennial National Listing of Fish Advisory; EPA-820-F-11-014; USEPA: Washington, DC, USA, 2011.

8. Jaffe, D.; Prestbo, E.; Swartzendruber, P.; Weisspenzias, P.; Kato, S.; Takami, A.; Hatakeyama, S.; Kajii, Y. Export of atmospheric mercury from Asia. Atmos. Environ. 2005, 39, 3029-3038. [CrossRef]

9. Lin, C.-J.; Pehkonen, S.O. The chemistry of atmospheric mercury: A review. Atmos. Environ. 1999, 33, 2067-2079. [CrossRef]

10. Obrist, D.; Kirk, J.L.; Zhang, L.; Sunderland, E.M.; Jiskra, M.; Selin, N.E. A review of global environmental mercury processes in response to human and natural perturbations: Changes of emissions, climate, and land use. Ambio 2018, 47, 116-140. [CrossRef]

11. Zhang, L.; Wright, L.P.; Blanchard, P. A review of current knowledge concerning dry deposition of atmospheric mercury. Atmos. Environ. 2009, 43, 5853-5864. [CrossRef]

12. Hall, N.L.; Dvonch, J.T.; Marsik, F.J.; Barres, J.A.; Landis, M. An Artificial Turf-Based Surrogate Surface Collector for the Direct Measurement of Atmospheric Mercury Dry Deposition. Int. J. Environ. Res. Public Health 2017, 14, 173. [CrossRef]

13. Huang, J.; Lyman, S.N.; Hartman, J.S.; Gustin, M.S. A review of passive sampling systems for ambient air mercury measurements. Environ. Sci. Process. Impacts 2014, 16, 374-392. [CrossRef] [PubMed]

14. Huang, J.; Choi, H.-D.; Landis, M.S.; Holsen, T.M. An application of passive samplers to understand atmospheric mercury concentration and dry deposition spatial distributions. J. Environ. Monit. 2012, 14, 2976-2982. [CrossRef] [PubMed]

15. Lyman, S.N.; Gustin, M.S.; Prestbo, E.M.; Kilner, P.I.; Edgerton, E.; Hartsell, B. Testing and Application of Surrogate Surfaces for Understanding Potential Gaseous Oxidized Mercury Dry Deposition. Environ. Sci. Technol. 2009, 43, 6235-6241. [CrossRef] [PubMed]

16. Sprovieri, F.; Pirrone, N.; Ebinghaus, R.; Kock, H.; Dommergue, A. A review of worldwide atmospheric mercury measurements. Atmos. Chem. Phys. Discuss. 2010, 10, 8245-8265. [CrossRef]

17. Gustin, M.S.; Jaffe, D. Reducing the Uncertainty in Measurement and Understanding of Mercury in the Atmosphere. Environ. Sci. Technol. 2010, 44, 2222-2227. [CrossRef]

18. Lyman, S.N.; Gustin, M.S.; Prestbo, E.M.; Marsik, F.J. Estimation of Dry Deposition of Atmospheric Mercury in Nevada by Direct and Indirect Methods. Environ. Sci. Technol. 2007, 41, 1970-1976. [CrossRef]

19. Zhang, L.; Lyman, S.; Mao, H.; Lin, C.-J.; Gay, D.A.; Wang, S.; Gustin, M.S.; Feng, X.; Wania, F. A synthesis of research needs for improving the understanding of atmospheric mercury cycling. Atmos. Chem. Phys. Discuss. 2017, 17, 9133-9144. [CrossRef]

20. Prestbo, E.M.; Gay, D. Wet deposition of mercury in the U.S. and Canada, 1996-2005: Results and analysis of the NADP mercury deposition network (MDN). Atmos. Environ. 2009, 43, 4223-4233. [CrossRef] 
21. Zhang, L.; Wu, Z.; Cheng, I.; Wright, L.P.; Olson, M.L.; Gay, D.A.; Risch, M.R.; Brooks, S.; Castro, M.S.; Conley, G.D.; et al. The Estimated Six-Year Mercury Dry Deposition Across North America. Environ. Sci. Technol. 2016, 50, 12864-12873. [CrossRef]

22. Era-Miller, B. Toxics Atmospheric Deposition in Eastern Washington State-Literature Review; EA Project Code 10-124; Washington State Department of Ecology: Olympia, WA, USA, 2011.

23. Yi, S.-M.; Holsen, T.M.; Noll, K.E. Comparison of Dry Deposition Predicted from Models and Measured with a Water Surface Sampler. Environ. Sci. Technol. 1997, 31, 272-278. [CrossRef]

24. Sakata, M.; Marumoto, K. Dry Deposition Fluxes and Deposition Velocities of Trace Metals in the Tokyo Metropolitan Area Measured with a Water Surface Sampler. Environ. Sci. Technol. 2004, 38, 2190-2197. [CrossRef] [PubMed]

25. Waite, D.T.; Snihura, A.D.; Liu, Y.; Huang, G. Uptake of atmospheric mercury by deionized water and aqueous solutions of inorganic salts at acidic, neutral and alkaline pH. Chemosphere 2002, 49, 341-351. [CrossRef]

26. United State Environmental Protection Agency (USEPA). Method 1631, Revision E: Mercury in Water by Oxidation, Purge and Trap, and Cold Vapor Atomic Fluorescence Spectrometry; EPA-821-R-02-019; USEPA: Washington, DC, USA, 2002.

27. Landis, M.S.; Keeler, G.J. Critical Evaluation of a Modified Automatic Wet-Only Precipitation Collector for Mercury and Trace Element Determinations. Environ. Sci. Technol. 1997, 31, 2610-2615. [CrossRef]

28. MesoWest Data. Applicable mean daily values accessed for Pullman station KPUW and Puyallup station PLU. Available online: mesowest.utah.edu/ (accessed on 1 March 2013).

29. Western Regional Climate Center. Data reported for Pullman measured in nearby Moscow, Idaho and for Puyallup measured at Puyallup 2 West Experimental Station. Available online: www.wrcc.dri.edu/ (accessed on 1 March 2013).

30. Sakata, M.; Asakura, K. Evaluating Relative Contribution of Atmospheric Mercury Species to Mercury Dry Deposition in Japan. WaterAirSoil Pollut. 2008, 193, 51-63. [CrossRef]

31. Sakata, M.; Marumoto, K.; Narukawa, M.; Asakura, K. Regional variations in wet and dry deposition fluxes of trace elements in Japan. Atmos. Environ. 2006, 40, 521-531. [CrossRef]

32. Lai, S.-O.; Huang, J.; Hopke, P.K.; Holsen, T.M. An evaluation of direct measurement techniques for mercury dry deposition. Sci. Total. Environ. 2011, 409, 1320-1327. [CrossRef]

33. Marsik, F.J.; Keeler, G.J.; Landis, M.S. The dry-deposition of speciated mercury to the Florida Everglades: Measurements and modeling. Atmos. Environ. 2007, 41, 136-149. [CrossRef]

34. USEPA AirData Air Quality Monitors. Available online: https://epa.maps.arcgis.com/apps/webappviewer/index.html?id=5f2 39fd3e72f424f98ef3d5def547eb5\&extent=-146.2334,13.1913,-46.3896,56.5319 (accessed on 1 December 2020).

35. Cobbett, F.; Vanheyst, B. Measurements of GEM fluxes and atmospheric mercury concentrations (GEM, RGM and Hgp) from an agricultural field amended with biosolids in Southern Ont., Canada (October 2004-November 2004). Atmos. Environ. 2007, 41, 2270-2282. [CrossRef]

36. Bash, J.O.; Miller, D.R. A note on elevated total gaseous mercury concentrations downwind from an agriculture field during tilling. Sci. Total. Environ. 2007, 388, 379-388. [CrossRef]

37. Friedli, H.R.; Radke, L.F.; Prescott, R.; Hobbs, P.V.; Sinha, P. Mercury emissions from the August 2001 wildfires in Washington State and an agricultural waste fire in Oregon and atmospheric mercury budget estimates. Glob. Biogeochem. Cycles 2003, 17, 1039. [CrossRef]

38. Caldwell, C.A.; Swartzendruber, P.; Prestbo, E. Concentration and Dry Deposition of Mercury Species in Arid South Central New Mexico (2001-2002). Environ. Sci. Technol. 2006, 40, 7535-7540. [CrossRef]

39. O'Dell, K.; Ford, B.; Fischer, E.V.; Pierce, J.R. Contribution of Wildland-Fire Smoke to US PM2.5 and Its Influence on Recent Trends. Environ. Sci. Technol. 2019, 53, 1797-1804. [CrossRef]

40. Sprovieri, F.; Pirrone, N.; Bencardino, M.; D’Amore, F.; Angot, H.; Barbante, C.; Brunke, E.-G.; Arcega-Cabrera, F.; Cairns, W.; Comero, S.; et al. Five-year records of mercury wet deposition flux at GMOS sites in the Northern and Southern hemispheres. Atmos. Chem. Phys. Discuss. 2017, 17, 2689-2708. [CrossRef]

41. Gill, G. Task 3-Atmospheric Mercury Deposition Studies. In Transport, Cycling, and Fate of Mercury and Monomethyl Mercury in the San Francisco Delta and Tributaries: An Integrated Mass Balance Assessment Approach; Calfed Mercury Project 2008 Report; Moss Landing Marine Laboratory: Moss Landing, CA, USA, 2008. 